\title{
PASTORAAT IN MEDIESE KONTEKS
}

\section{DR. G. BAM.}

Die pastoraat in mediese konteks neem beide in die dissipline van die praktiese teologie sowel as in die dienswerk van die kerk van die Here Jesus Christus in hierdie wêreld vandag 'n besondere plek in. Van die verskeidenheid van vorme van gespesialiseerde pastoraat het die pastoraat in mediese konteks gedurende die afgelope half eeu moontlik die mees skouspelagtige ontwikkeling meegemaak. Vanuit die pastorale werk in hierdie konteks het daar ook baie sterk invloed uitgegaan na die pastoraat in die algemeen en ook die teologiese skole en die opleiding van predikante. Dink in hierdie verband aan die volgende:

1. Die opkoms van die moderne hospitaal as verskynsel in die mediese wêreld en die geleentheid wat dit skep vir die pastoraat aan die sieke. In die middel veertiger jare was daar bv. in die V.S.A. 'n twee tot drie dosyn predikante voltyds in hospitale werksaam. In die twintig jaar tot die middel sestiger jare het die getal gegroei tot 1400 terwyl daar verder nog 650 spesiaal opgeleide predikante in deeltydse diens was met ' $n$ minimum van tien uur diens per week. In S.A. is ons ver agter maar dit is tog iets merkwaardigs en 'n aanduiding van 'n nuwe benadering dat in die Kaapse Skiereiland die Ned. Geref. Kerk in S.A. tans drie poste vir voltydse hospitaalleraars het terwyl daar vier jaar gelede nie 'n enkele een was nie. Die arbeid is in die kort tyd in dié mate gevestig dat die werk stadigaan reeds 'n sekere eie karakter begin ontwikkel.

2. Die massa literatuur wat in dié verband in die vorm van proefskrifte, navorsingsverslae, boeke en tydskrifte verskyn. Die produktiwiteit in hierdie verband is nie beperk tot een kerk of een land nie.

3. Die invloed van die sgn. kliniese opleiding van predikante in hospitale op die teologiese skoling van universiteite en seminaries. Praktiese teologie word minder teorie en meer konkreet terwyl dit begin rekening hou het, in die begin met die resultate van navorsingswerk in die veld van die psigologie, en later ook van die sosiologie en selfs ook begin het om vanuit 'n teologiese verwysingsraamwerk empiriese studies te onderneem.

Alhoewel die teologie in hierdie verband in die beginjare deur 'n skisofriniese gesteldheid bedreig was, word daar met sukses gewerk om hierdie nuwe wêreld wat vir die teologie oopgegaan het op verantwoorde wyse te inkorporeer in die teologiese materiaal. 
In S.A. is die teologie nog nie op dieselfde wyse blootgestel aan die invloed van die kliniese beklemtoning as in sekere ander oorsese lande nie.

4. Die totstandkoming van kontak tussen die kerklik-godsdienstige en mediese wêrelde soos daar in geen jare sedert die ontwikkeling van die moderne mediese wetenskap was nie. Dit spruit o.m. voort uit die teenwoordigheid van die kerk in die hospitaal en die gevolglike opkoms van 'n groep predikante wat die taal van die mediese leefwêreld kan praat; uit die besef dat genesing nie net van die liggaam is nie maar die hele persoon raak en ook ander faktore. Ek dink hier bv. aan die totstand. koming van liggame soos die American Foundation of Religion and Psychiatry; die Acadamy of religion and Mental Health en ander soortgelyke liggame elders; die samewerking van mense uit die teologiese en mediese wêrelde op die radaksionele komitees van blaaie soos Journal of Religion and Health; Pastoral Psychology e.a.

5. Daar gaan vanuit die pastoraat in mediese konteks ' $n$ invloed uit op die pastoraat in die algemeen. Die werklike praktiese pastorale vorming wat die voornemende leraar ontvang, waardeur sy pastorale habitus in hoë mate bepaal word, word - vir sover as wat dit gedoen word - feitlik vir 99 persent in mediese konteks gedoen. Daar is goeie redes waarom dit so geskied en dit het ook voordele, maar dit het, met die oog op die gewone pastoraat, ook ernstige nadele.

Hierdie verwysinge is seker voldoende om die aanvangsstellinge te motiveer.

Nou is dit nodig om op hierdie stadium die terme van die opdrag te verklaar. Vir ons doel hier is die pastorale werk daardie sorg waarin die bedienaar van die Woord in die besondere amp, herderlik met die enkele lid van die kudde omgaan, diensbaar aan die woord van God wat genesend, ondersteunend, leidend en vermanend werksaam wil wees in die lewe van hierdie mens, met die oog daarop dat hy groei tot volwasse persoon in Christus Jesus die Here.

Ook persone in die algemene amp van die gelowige het 'n pastorale funksie om te vervul, in die algemeen en ook in mediese konteks. Die Christen verpleegsters en geneesheer het 'n getuienis om te lewer en hulle verkeer in 'n baie gunstige posisie om besondere diens aan die Koninkryk van God te kan lewer. Oor hierdie diens gaan dit nie in hierdie stuk nie.

Die woord medies kom van die latynse werkwoord mēdere: om te genees en die selfstandige naamwoord medicus: geneesheer. Medies is dus dit wat in verband staan met die genesing. 
Mediese konteks is dan daardie stuk leefwêreld waar die mediese en paramediese dienste, mense, wat aan genesing behoefte het, ontmoet. Waar daar behoefte is aan genesing, daar is die geneesheer noodsaaklik teenwoordig.

Wanneer daar sprake is van pastoraat in mediese konteks dan sal die pastor met twee soorte mense in aanraking kom: hulle wat die genesing soek - die pasiënte - en hulle wat werk om genesing te bring - die geneeshere en hulle span.

In die stuk verderaan wil ek graag aandag gee aan die pastoraat aan beide groepe. Dit is onmoontlik om maar by benadering selfs elke aspek van hierdie omvangryke veld te vermeld. Ek wil dan aanbeveel dat twee werke oor die siekepastoraat nl. P. J. Roscam Abbing: Pastoraat aan Zieken en R. C. Cabot en R. L. Dicks: The Art of Ministering to the Sick deel sal vorm van die besprekingsmateriaal vir hierdie onderwerp in soverre daar behoefte sal wees om punte te opper wat nie in hierdie referaat aandag aan gegee kan word nie.

Tussen die mense wat almal in die bedryf van genesing betrek geraak het, is dit nodig om vir pastorale doeleindes veral dokters en verpleegsters uit te sonder vir besondere aandag vanweë hulle eiesoortige werksprogram en vanweë 'n leefwêreld wat ervaringe en verantwoordelikhede van 'n besondere kwaliteit meebring.

Die kerk het nodig om in sy pastoraat aan die medici veel meer in hulle leefwerreld in te kom. Hy moet so inheems word dat nie net hy dink dat hy verstaan wat die mense aan geleenthede en verantwoordelikhede en probleme beleef nie, maar dat die medici begin ervaar en erken dat die kerk verstaan . . . hulle taal verstaan en iets van die werklikhede waarvan die taal vertel.

'n Christendokter loop 'n werklike gevaar om 'n gesplete bestaan te voer. Hy verstaan homself dan as man van geloof en godsdiens en as man van wetenskap. Hy het 'n kerklik-godsdienstige identiteit en 'n professionele identiteit wat in afgeslote kompartemente bestaan. In die een afdeling werk hy met die naakte werklikheid van die lewe. Hy sien die dood en veg om die dreiging van die siekte oor die lewe af te wend. Hy neem daagliks beslissinge met ingrypende moreel-sedelike implikasies - nie noodwendig oor die groot beginsels wat hom moet lei nie maar wel oor die praktiese toepassing van die beginsels. Hy dra uitputtende verantwoordelikheid. Uit sy kerklik-godsdienstige lewe moet hy lewensbeskouing en lig en krag vir sy professionele bestaan ontvang. Maar in die ter sake meningvormende proses, waarin sy houding en waardes wat sy besluite bepaal, gegiet word, is die kerk en die godsdiens, sy kerk en sy godsdiens, dikwels vir hom baie verhef en irrelevante gestaltes. In die mediese 
meningvorming en praktyk oor die genadedood, oor aborsie, oor voorbehoedmiddels en sterilisasie, oor orgaanoorplanting en al die etiese vrae wat daarmee saamhang, praat die kerk en die medici meermale asof uit twee afgeslote ruimtes. Die kerk sal in S.A. veel meer inheems moet word in die mediese wêreld indien hy geneeshere in die pastoraat betekenisvol wil ontmoet sodat die medikus nie net verveeld-hoflik sal wees teenoor 'n ou geëerde instelling nie, maar hy die diens van die kerk aan hom as werklik ter sake diens sal ervaar en hy gewaar word dat hy as mens in hierdie besondere leefwêreld en oor hierdie besondere uitdaginge en verantwoordelikhede en beslissinge gehelp word om as gelowige mens te leef en te kom tot die eenheid van die geloof en van die kennis sodat die kloof tussen die mens van die godsdiens en die mens van die mediese wetenskap oorbrug kan word.

Die plek waar die deurbraak na die mediese wêreld hom moet voltrek, is in en in verband met die hospitaal. Die kerk sal die hospitale meer en meer moet beman met personeel wat nie net opdrag het tot pasiëntesorg nie, maar tot indringing in die leefwêreld van die geneesheer met die oog op diens terwille van die Here Jesus Christus. Indien hy ervaar dat die kerk met hom saam na sy werk gaan en in daardie leefwêreld met hom ter sake kan praat oor die werklikheid van die Here Jesus Christus, sal dit bydra om sy verbintenis met die gemeente betekenisvol en waardevol uit te bou en dit sal hom slyp tot getuie van die Here Jesus Christus in sy werk. Maar dit gaan hier nie net om die bereiking van die enkeling dokter nie maar 'n deurdringing van die pastoraat tot die lewensstrukture van die mediese leefwêreld as sodanig. Dit gaan in die pastoraat aan die medikus nie net om sy persoon nie, maar ook om sy wêreld.

Hierdie pastorale diens van die medikus aan die mediese wêreld mag ook in die hospitaal nooit los van kerkverband gedoen word nie en mag nooit plaasvervangend van die gemeentelike sorg wees nie maar ter aanvulling. Wanneer ek sê dat die deurbraak tot die mediese wêreld hom in die hospitaal moet voltrek dan skakel ek nie die betekenisvolle kontak tussen 'n predikant en 'n dokter in 'n gegewe gemeenskap, rondom 'n gegewe pasiënt of vanweë die pastorale sorg aan sy eie lewe, uit nie. Dit moet en sal gebeur. Maar dit sal nooit die hoof-invalspoort kan word vir die kerk om weer 'n ter sake meningvormende krag te word in die mediese wêreld nie. Die deurbraak sal via die hospitaal moet kom waar medikus en pastor skouer aan skouer werk.

Wat vir die dokter geld, geld in 'n sekere sin ook van die verpleegster. Die praktyk wys dit uit dat sy meer betekenisvol 
bereik kan word deur 'n kerklike diens wat inheems in die hospitaal maar sterk gemeentelik gebind is, as deur 'n diens wat net vanuit die gemeente gelewer word. Met die pastorale sorg aan verpleegsters en die inheemswording in die verpleegsterswêreld is ons kerke oor die algemeen verder gevorder as met die sorg aan die medici.

Hoe belangrik die pastoraat wat in die mediese leefwêreld op die bedienaars van die genesing gerig is ookal mag wees, mag dit nooit iets afdoen aan die diens van die kerk aan die pasiënt nie. Per slot van rekening is die mediese leefwêreld daar omdat daar pasiënte is.

Alhoewel die pastor die pasiënt ook op ander plekke sal teenkom - bv. in die siekekamer of in die tehuis vir bejaardes sal die ontmoeting in ons moderne samelewing hoofsaaklik in die hospitaal plaasvind. Vanweë die besondere gespesialiseerdheid van mediese versorging en behandeling, vanweë die omvang en gewildheid van chirurgie as wapen teen siekte en vanweë ander redes word siek mense meer en meer in hospitale saamgetrek. Soms ontstaan daar die gevoel dat indien iemand nie siek genoeg is om hospitaal toe te gaan nie hy ook nie siek genoeg is om as sieke die voorwerp van besondere pastorale bemoeienis te wees nie.

Terwyl dit in die algemeen so is dat liggaamlik siek pasiënte tydens die krisis van hulle siekte steeds meer uit die samelewing in hospitale saamgetrek word, is daar 'n ander ewe belangrike tendens merkbaar wat die geestessiek pasiënte betref. Deur moderne middele word die simptome van die geestessiekte dikwels baie vinnig en doeltreffend onder beheer gekry. Langs dié weg word daarin geslaag om 'n groot aantal pasiënte wat enkele jare gelede nog vir lang tye gehospitaliseer sou moes word, nou binne korte tyd in die samelewing terug te plaas. Hier het die pastor in sy gemeente met 'n gekamoufleerde siekte te doen een wat ernstig siek is maar simptoomvry a.g.v. die chemoterapeutiese middele wat hy daagliks moet gebruik. Hierdie mense moet in die gemeente voorwerp van besondere sorg wees. Belangrik in hierdie verband is begrip vir die mediese oordeel oor en program vir die pasiënt. Nie dat dit absolute voorskrifte vir die pastor mag wees. Daar moet ruimte wees vir 'n eie pastorale oordeel. En in dié verband is van groot belang dat die pasiënt in die hospitaal doeltreffend deur die hospitaalleraar bereik word en dat tussen hom en die plaaslike leraar m.b.t. die pastorale sorg aan die persoon goeie oorleg en verstandhouding sal wees. 
Daar is natuurlik ook ander pasiënte wat uit die hospitaal nog as siek mense in die samelewing teruggeplaas word terminale pasiënte en mense met kroniese aandoeninge. Maar hulle is nie so onopsigtelik as die groep psigiatriese pasiënte nie. Hulle word weer op 'n ander wyse deur hulle siekte geraak en hulle mediese omstandighede en geestelike behoeftes is ook weer anders.

Wanneer die predikant in die hospitaal kom werk - as leraar wat een van sy lidmate besoek maar veral as hospitaalleraar wat voltyds daar werk, dan word hy baie pertinent voor die vraag na eie identiteit van die pastorale sorg van die sieke gestel.

In die gemeente het die predikant eie identiteit. In die beskermde wêreld van die gemeente het hy 'n beskermende en betreklik duidelik gedefinieerde funksie. Hy bedien woord en sakrament en vanuit hierdie diens wat vir hom gereserveer word, kry sy hele bediening karakter. Wanneer die predikant uit die gemeente na die spesiale pastoraat beweeg bv. in die bedryf of as polisieof leërkapelaan dan word die identiteit nie diepgaande bevraagteken nie. Hy kom nie om 'n bydrae te lewer tot werk wat reeds in die bedryf of in die groep gedoen word nie. Hy kom om gespesifiseerde predikantswerk te verrig. Rondom hierdie kern mag daar allerlei ander dinge op sy weg kom, maar die kern van sy diens is duidelik geĩdentifiseer. In die mediese konteks is dit meteens anders - indien die praktyk die volle draagwydte van die begrip pastorale sorg wil dek. Dit is natuurlik om in die hospitaal pastoraat te bedryf volgens die uitgediende antropologiese kyk op die mens wat siel en liggaam op so 'n wyse skei dat medici en geestelikes elkeen ongestoord op sy eie terrein kan beweeg, elkeen hard besig om diens te lewer aan die stuk van die mens wat hy as sy verantwoordelikheid reken. Maar hierdie manier van doen is vandag nie meer verantwoord nie. Daarvoor het die besef van die mens as eenheid te sterk deurgebreek en is die bewyse van die onderlinge vervlegtheid van gees en liggaam te oorweldigend. Bedink hierby nog dat in terme van die definisie van pastorale sorg hierbo, genesing ' $n$ integrale deel is van die pastorale sorg en dan word dit duidelik dat die pastor in mediese konteks nou weer baie duidelik sal moet sê wie hy is en wat hy wil. Hy bevind hom hier in die geselskap van mense wat op baie effektiewe wyse die genesing dien. En wanneer hy langs hulle staan met die pretensie om ook die genesing te dien dan moet hy baie duidelik identiteit verklaar. Die pastoraat mag nie met mindere pretensie in die mediese konteks dien nie maar dan moet die diens van genesing ook nooit losgemaak word uit die totale pastorale konteks soos in die definisie aangegee nie. Terwyl 
die medici die genesing meer soek as doel in sigself soek die pastoor dit meer as teken van die koninkryk. Die pastoraat is nooit bloot medies in die genesing geinteresseerd nie.

Die pastoraat mag die diens tot genesing nie aan die medici prysgee nie. En tog is dit in Suid-Afrika in hoë mate gedoen. Genesing, so word dan stilswyend geoordeel, behoort by die medici of by die sektes. Tussen die uiterstes: diens gebou op die grondbeginsels van die natuurwetenskap deur die medici en diens gebou op die grondbeginsels van die godsdiens deur sektariese geloofsgenesers huiwer die pastoraat in onsekere en angstige neutraliteit. Simptomaties hiervan is die volgende twee vermeldinge: 'n hospitaalleraar word bevestig. Die rede gaan oor Hand. 3 , die siek mens op die trappe van die tempel en die diens wat die amp aan hierdie mens in nood lewer. Dit is 'n boeiende rede wat die gedagtes van die Skrif pragtig ontwikkel tot op 'n punt want nie 'n enkele maal word die woord ,genesing" beskrywend van die diens van die kerk aan die siek mens nie. En dit is tog wat in Handelinge 3 gebeur het. Die een kardinale punt is dat die siek mens deur die diens van die kerk gesond geword het.

'n Jong predikant stel baie belang in die verskynsel van die genadegawe tot gesondmaking. Daar is aanduidinge dat hy die gawe ontvang het. Maar hy onttrek hom doelbewus aan die beoefening daarvan omdat daar in sy kerk nie ruimte is vir die ontplooiing van hierdie gawe nie.

Wat is die eie identiteit dan van die pastor wanneer hy in mediese konteks werk? Is hy 'n gewone besoeker by die pasiënt in dieselfde kategorie as al die ander wat gedurende besoektyd hul opwagting maak, alhoewel hy buitenstyd binnegelaat word? Verteenwoordig hy die primitiewe, onverligte benadering tot siekte teenoor die wetenskaplik-moderne aanpak? Verteenwoordig hy die irrasionele magte en faktore teenoor die rasionele? Verteenwoordig hy die ou uitgediende stand teenoor „the new clergy"? Verteenwoordig hy vanselfsprekend die krag van die Heilige Gees teenoor die menslike vermoë? Dien hy die siel en die ander die liggaam? Soek hy om van sonde te genees terwyl die ander soek om van siekte te genees? Dien hy op die hoëre niveau die "vryheid tot" van die mens terwyl die ander op die laere niveau die „vryheid van" die mens dien? Het hy die besondere reg om die woord en die gebed in die stryd teen die siekte te gebruik terwyl die ander prakties uitgesluit is van die middele? Nie een van hierdie teenoorstellinge dek die volle waarheid nie.

Die besondere eiesoortigheid van die pastorale diens moet gesoek word in die feit dat in hom twee dimensies op 'n besondere wyse mekaar ontmoet. Hy dien op 'n besondere wyse in en 
ook namens God. Hierdie twee dimensies van sy diens mag nie van mekaar geisoleer word nie. Indien die volledige verbande gehandhaaf bly dan dien beide namens die gemeente en namens God in 'n veel meer gelade sin as wat enige ander persoon dit kan doen. Hy verteenwoordig die gemeente en hy verteenwoordig God op meer besondere wyse as enige ander persoon. Vanuit hierdie agtergrond dien hy. En elke middel wat van God deur die gemeente tot beskikking van die siek mens tot sy genesing staan, moet deurdie pastor aan hom bedien word of van gebruik gemaak word in sy diens aan hom. Hy moet in die gesprek luister na die belydenis; hy moet die woord bedien; hy moet bid; hy moet die gemeenskap van die heiliges verteenwoordig en die pasiënt help om iets daarvan te ervaar; hy moet die gawe tot gesondmaking gebruik; hy moet verneem van die sonde en die vergiffenis meedeel en nog soveel meer. Moderne mediese ervaring weet en besef dat hierdie middele ' $n$ magtige faktor in genesing is. Hierdie middele en diens is uiteraard nie die enigste wat die pasiënt vanweë God ten dienste staan nie. God bedien hom m.b.t. die sieke veral ook van die gewone mediese middele.

In S.A. moet die predikant in die mediese leefwêreld nog 'n aanvaarde plek vind volgens die nuwe patroon. As besoeker het hy deur al die jare nog toegang tot die pasiënt gehad. Soms word hy waardeer en soms net geduld en reg met agterdog bejeën. Maar besoeker beskryf nog weer heeltemal 'n ander verhouding as medewerker. Die pastor moet in mediese konteks nog vir hom 'n plek verower as medewerker wat bewustelik op sy eie manier soek om die vole genesing te dien.

In hierdie verband sal die pastor baie versigtig moet wees om nie sy pastorale identiteit in te boet en as pseudo-terapeut te funksioneer nie. Om in die hospitaal hierdie gevaar die hoof te bied, moet die pastorale diens aldaar steeds baie sterk kerklik gebind bly. In die V.S.A. is dit nie so nie en dit is m.i. een van die redes waarom die diens daar in ernstige identiteitskrisis gedompel was. Die pastorale diens mag nooit die diens van 'n geisoleerde persoon word nie, maar moet steeds volwaardige kerklike diens wees.

Hierdie arbeid sal gespesialiseerde diens moet wees. As die pastor saam met die geneesheer as 'n eenheid wil funksioneer die ,comprehensive approach" — dan is dit 'n ontontbeerlike voorvereiste dat hy die taal en werksmetode van die medikus moet verstaan. Die mediese wêreld is vandag so uitgebreid en so gespesialiseerd dat dit toegewyde studie en kliniese ervaring oor jare heen vra om werklik as ingewyde te kan werk. En alleen 
langs hierdie weg kan vertroue opgebou word. Hiermee hang saam natuurlik die nodige kennis aangaande die siek mens en die invloed van siekte op die gees van die mens.

Wat kan die kerk doen om homself in die mediese konteks inheems te maak? Ons kan moeilik vandag, soos die vroeë manne van die kliniese beweging in die V.S.A. as „orderlies" in die hospitaal gaan werk. Ons sal deur kwaliteits pastorale diens erkenning moet verwerf. Ons werk teen sterk teenstand in. Terwyl die ou dualistiese antropologie ook as mediese model oorwin is, het daar in die mediese wêreld groter besef gekom van die woorde van die geestelike dimensie in die menslike persoonlikheid. Maar instede van die kerk nader te trek in die diens van genesing het die geneeskunde sy eie ,geestelikes" gaan skep in die persone van die psigiaters en kliniese sielkundiges. Ook die geestelike mens word in die sorg vollediglik gesekulariseer.

In hierdie klimaat moet die pastor homself bewys deur sy diens as een wat wel deeglik 'n betekenisvolle bydrae te lewer het. Hy moet veel vooroordeel oorwin en die beeld wat die geneesheer dikwels van hom het as leek wat nie verstaan nie, aflewe, sodat hy as kollega erken kan word. Dit alles is nie so maklik nie omdat die diens van die pastor nie so konkreet en spesifiek is soos bv. die van die narkotiseur of chirurg of internis nie. Twee goedgesinde geneeshere wat wenke aan die hand gedoen het om die verhouding tussen geneesheer en predikant te bevorder, het soos volg aanbeveel:

„Die probleem waarvoor hier gestaan word, is dat die predikant nie die nodige tegniese kennis het om 'n duidelike beeld te vorm van die probleme waarmee die pasiënt te kampe het nie en aan die ander kant is die geneesheer nie altyd daarvan oortuig dat die predikant wel 'n bydrae te lewer het in die totale sorg van die pasiënt nie. Hierdie basiese probleem word verder benewel deur taalverskille en godsdienstige en kerklike verskille van sommige hospitale.

\section{Oplossing:}

Dit skyn asof die nodige oplossing kan wees om kontak te vermeerder tussen die twee groepe nl. predikant en geneesheer. As 'n interim-oplossing van die bestaande probleemsituasie sou'n mens wil voorstel dat daar algemene besprekings en lesings plaasvind vir kleiner groepe predikante deur geneeshere wat die probleme besef en die saak goedgesind is. Veral wil 'n mens in sulke omstandighede sien dat deelname aan die kant van die predikant vrae en probleemstellinge die vernaamste deel vorm. 'n Mens sou 
selfs verder in die toekoms wou sien dat groepe geneeshere toegespreek word deur 'n gesaghebbende predikant om die saak van die totale sorg van die pasiënt te stel.

Oor 'n lang termyn sou 'n mens wou aanbeveel:

(a) Besprekings tussen teologiese en mediese studente onder leiding van ' $n$ belanghebbende geneesheer en predikant. Weereens wil 'n mens beklemtoon dat openhartige vraag en antwoord en gesonde kritiek voorkeur sal geniet.

(b) Om die begrip by die predikant van die basiese feite in verband met fisiologie, patologie en behandeling by te bring. 'n Mens sou wou voorstel 'n groep lesings oor hierdie basiese elemente van die medisyne sodat hulle kennis daarvan meer sal wees en hulle begrip daarom beter as dié van die leek in die algemeen.

(c) In hierdie verhouding van predikant tot geneesheer sou 'n mens wou sien dat in spesiale gevalle die predikant direkte toegang tot die hoofgeneesheer van 'n pasiënt in 'n saal kan kry in verband met die sorg van 'n pasiënt aangesien dit tog waarskynlik is dat 'n predikant somtyds informasie sal verkry van 'n pasiënt wat nie aan 'n verpleegster, junior- en hoofdokter of ander arts verstrek sal word nie. Sulke informasie mag desnieteenstaande baie belangrik wees in die sorg van die pasiënt. Ons is seker dat selfs 'n klein briefie van die dominee aan die geneesheer, kort, bondig en feitlik, veel sal doen in die besondere geval om die pasiënt te help en ook om die geneesheer te laat begryp dat die predikant op wyer vlak die sorg van die pasiënt op die hart dra."

Pastoraat in mediese konteks leen homself vanweë die gekontroleerde situasie tot navorsingswerk. Hiervan het in S.A. feitlik nog niks tereg gekom nie. Maar dit is een van die maniere waarlangs samewerking en gevolglike kontak met die mediese leefwêreld gemaak kan word. 'n Massa navorsingsmateriaal het deur die gekontroleerde pastorale sorg in kliniesmediese konteks beskikbaar geword. Die reeks publikasies „Successful Pastoral Counselling" sou volgens die redakteur Russel L. Dicks, 'n kwart eeu gelede nie moontlik gewees het nie omdat die materiaal nie beskikbaar was nie. Meeste van die skrywers het hulle pastorale vorming in die mediese leefwêreld ontvang en hulle bronnemateriaal daar ontleen. Hier werk die pastor in 'n atmosfeer van navorsing waarin dit nie vreemd sou wees indien hyself ook sy optrede en metodes wetenskaplik krities beskou met die oog op meer doeltreffende pastorale diens. Wanneer hier die navorsing en skoling beklemtoon word, moet onthou word dat dit maar een aspek van die pastorale vorming is. 
Daar is die kardinale toerusting deur die Heilige Gees van God en ander vorme van bekwaammaking en toerusting wat van buite die mediese konteks kom.

$\mathrm{Na}$ alles wat tot dusver gesê is, mag dit voorkom asof dit alleen enkele hospitaalleraars is wat in mediese konteks pastorale werk verrig. Dit is nie so nie. Predikante staan daagliks by die siekbed van gemeentelede en die siekepastoraat vorm 'n belangrike en meestal vrugbare afdeling van die algemene pastorale sorg in die gemeente. Maar nou is dit dikwels so dat die siekepastoraat in die gemeente feitlik geheel en al buite die mediese konteks om gedoen word. Die predikant kom by die sieke sonder om hoegenaamd kontak met die geneesheer te hê. Alhoewel dit nie in elke individuele geval nodig is nie, bly dit in die algemeen tog 'n vereiste dat die predikant rondom die pasiënt kontak soek met die geneesheer sodat daar ook spontane en natuurlike verwysing oor en weer kan wees.

Stel die pastoraat in mediese konteks besondere eise aan die pastor bo en behalwe die eise van die algemene pastoraat? 'n Besondere kennis van die mediese leefwêreld en van die sieke en siektes moet as vereiste gestel word. Daarbenewens moet die predikant in 'n span kan saamwerk; die vermoë besit om siekte te kan sien en beleef sonder om self daardeur siek gemaak te word; die vermoë tot egte eenvoudige ontmoeting met mense in die krisis val alle tierlantyntjies weg; die vermoë om waarlik mens te kan bly. Die vermoë om trane te kan hanteer, om enkele te noem. Die werk stel dus ook sy besondere eise.

Pastoraat in mediese konteks - die kerke in S.A. is net maar aan die begin van 'n besef van die geweldige geleenthede en moontlikhede wat daar aan die kerk gegee word wanneer hy doelbewus werk om in die mediese leefwerreld staanplek te verower as medewerker. Ter wille van die Here Jesus Christus, ter wille van die medici, ter wille van die pasiënte en ter wille van homself mag die kerk hier nie versuim nie. As die kerk vir die siek mens nie doeltreffend dien nie en nie ter sake is nie, loop hy gevaar om vir die gesonde mens steeds meer en meer irrelevant te word. 